Małgorzata Michalewska-Pawlak

Uniwersytet Wrocławski

\title{
Unia Europejska wobec paradygmatu inwestycji społecznych*
}

DOI: 10.19195/1643-0328.23.7

Słowa kluczowe: inwestycje społeczne, polityka społeczna, kapitał ludzki, kapitał społeczny, Unia Europejska, aktywizacja społeczna, ewaluacja

\section{Wprowadzenie}

Celem niniejszego artykułu jest prezentacja stanowiska Komisji Europejskiej (KE) wobec założeń nowego inwestycyjnego paradygmatu polityki społecznej oraz wyjaśnienie, dlaczego jest on rekomendowany jako optymalny model wspierania rozwoju kapitału ludzkiego i społecznego w Unii Europejskiej (UE). Analiza poprzedzona zostanie wskazaniem przyczyn wzrostu zainteresowania inwestycyjnym podejściem w realizacji polityki społecznej w Europie oraz charakterystyką jego głównych cech. Jakkolwiek badacze definiujący koncepcję inwestycji społecznych zwracają uwagę na różne elementy charakteryzujące nowy paradygmat, można wyróżnić pewne wspólne im cechy. Istotnym aspektem analizy działań KE na rzecz wzmocnienia wymiaru inwestycyjnego w polityce społecznej państw członkowskich jest zdiagnozowanie możliwości wywierania w tym zakresie na nie wpływu. Dla empirycznego zobrazowania koncepcji inwestycji społecznych w kontekście szerokich celów, jakie mają realizować, w dalszej części artykułu zaprezentowane zostaną dwa wybrane studia przypadków takich inwestycji, wdrażane obecnie w wybranych państwach europejskich. Kryterium ich doboru stanowiła chęć prezentacji tych rozwiązań, które traktowane są jako innowacyjne w praktyce zarządzania rozwojem społecznym tychże państw. Wybrane studia przypadków dotyczą: instytucji finansowej Big Society Capital, która powstała w Wielkiej Brytanii w celu wspierania innowacyjnych inicjatyw społecznych, oraz Rządowego Programu na rzecz Aktywizacji Społecznej Osób Starszych ASOS realizowanego w Polsce od 2012 r.

* Artykuł powstał w wyniku realizacji projektu badawczego Innovative Social Investment: Strengthening Communities in Europe, InnoSI, nr 649189, finansowanego przez Komisję Europejską z programu Horizon 2020-EU.3.6. 
Artykuł kończy się podsumowaniem zawierającym wnioski z przeprowadzonej analizy oraz wskazuje na kontrowersje związane $\mathrm{z}$ realizacją inwestycyjnego paradygmatu w polityce społecznej.

Przegląd dostępnej literatury przedmiotu wskazuje, że temat inwestycji społecznych jest szeroko omawiany zarówno w debacie naukowej, jak i dyskursie politycznym w Europie Zachodniej, natomiast w polskojęzycznej literaturze naukowej jest to obszar nadal posiadający znaczny potencjał analityczny. Polscy badacze rzadziej zajmują się samą koncepcją inwestycji społecznych ${ }^{1}$, częściej natomiast skupiają się na analizie proinwestycyjnych rozwiązań funkcjonujących w polityce społecznej².

Oprócz literatury przedmiotu w artykule wykorzystane zostały także materiały źródłowe i dokumenty dotyczące inwestycji społecznych, odnoszące się głównie do poziomu europejskiego, raporty badawcze na temat wdrażania paradygmatu inwestycyjnego w UE oraz źródła internetowe.

\section{Geneza debaty nad inwestycyjnym paradygmatem w polityce społecznej w Unii Europejskiej}

Debaty dotyczące optymalnego modelu wsparcia rozwoju społecznego nie są niczym nowym na forum UE. Są one podejmowane chociażby w związku z niską efektywnością polityki społecznej zachodnich państw dobrobytu, która okazała się niewystarczającą odpowiedzią na tradycyjne problemy społeczne związane $\mathrm{z}$ bezrobociem, wykluczeniem społecznym i ubóstwem, kryzysem demograficznym czy niską jakością kapitału społecznego ${ }^{3}$.

W ostatnich latach, w związku z kryzysem gospodarczym, postępującym procesem starzenia się europejskiego społeczeństwa, skutkami społecznymi globalizacji i presji międzynarodowej konkurencyjności, potrzeba dyskusji nad efektywnym modelem wspierania rozwoju kapitału ludzkiego oraz inkluzji społecznej uległa wzmocnieniu. W sposób szczególny na przebieg debaty nad europejskim modelem wsparcia społecznego wpłynęły dwa wydarzenia. Jednym z nich był kryzys ekonomiczny, którego apogeum przypadło na rok 2008. Obnażył on słabości polityk społecznych państw członkowskich,

${ }^{1} \mathrm{O}$ inwestycjach społecznych piszą m.in.: M. Grewiński, Inwestycyjna polityka społeczna. Nowy paradygmat państwa dobrobytu, [w:] Praca socjalna wobec wyzwań współczesności, t. 1, red. E. Bojanowska, M. Kawińska, Warszawa 2015, s. 291-309; A. Wiktorska-Święcka et al., Inwestycje społeczne jako nowy paradygmat polityk publicznych w Unii Europejskiej, Warszawa 2017.

2 Szerzej zob.: A. Cieplewska-Kowalik, Znaczenie rozwoju powszechnego systemu ustug opieki i edukacji przedszkolnej w Polsce. W stronę nowego kontraktu społecznego wobec współczesnych wyzwań demograficznych, ekonomicznych i społecznych, „Prace Naukowe Uniwersytetu Ekonomicznego we Wrocławiu” nr 292, 2013, s. 163-176; K. Iglicka, Demograficzne wyzwania dla rynków pracy, polityk społecznych i bezpieczeństwa Europy Środkowej, „Polityka Społeczna” nr 1, 2013, s. 1-5; P. Michoń, Dzieciństwo w Bullerbyn czy z tiger mothers? Bycie dzieckiem a stawanie się szczęśliwym dorosłym - zastrzeżenia wobec stosowania perspektywy inwestycji społecznych w polityce społecznej, „Przegląd Socjologiczny” 63, 2014, z. 4, s. 93-106.

${ }^{3}$ M. Grewiński, Inwestycyjna polityka społeczna oparta na ustugach. W kierunku nowego modelu welfare state?, [w:] Innowacyjna polityka społeczna, red. idem, A. Karwacki, Warszawa 2015, s. 58-59. 
wskazując na ich niską efektywność w osiąganiu celów takich, jak walka z bezrobociem czy inkluzja społeczna. Drugim był brak sukcesów we wdrażaniu Strategii Lizbońskiej i Europejskiej Strategii Zatrudnienia, co przełożyło się na próbę wzmocnienia komponentu społecznego w realizacji kolejnej strategii UE - Europa 2020.

Zmiany demograficzne zachodzące wskutek dynamicznego przyrostu liczby osób $\mathrm{w}$ wieku poprodukcyjnym są tendencją stałą obserwowaną $\mathrm{z}$ różnym nasileniem we wszystkich krajach UE. Stanowi to wyzwanie dla systemu finansów publicznych, odnoszące się do zapewnienia świadczeń emerytalnych na odpowiednim poziomie oraz dostępu do usług społecznych dla ludzi starszych. Dotyczą one przede wszystkim rynku pracy i problemu z zagwarantowaniem wystarczającej ilości i jakości siły roboczej niezbędnej do funkcjonowania gospodarki europejskiej ${ }^{4}$.

Kryzys gospodarczy i jego skutki w postaci wzrostu bezrobocia, także wśród ludzi młodych, ubóstwa i ekskluzji społecznej, również odnoszącej się do osób pracujących i dzieci, stanowi nie tylko zagrożenie o charakterze społecznym, ale też wyzwanie z perspektywy konkurencyjności gospodarki europejskiej. Niewystarczająca jakość kapitału ludzkiego, niski poziom wykorzystania jego zasobów miały bezpośredni wpływ na rynek pracy w $\mathrm{UE}^{5}$. Jedną z przyczyn takiego stanu rzeczy był system kształcenia i szkoleń niedostosowany do potrzeb rynku pracy. Wzrost zagrożenia ubóstwem i wykluczeniem społecznym spowodował, iż w polityce wzrostu gospodarczego zaczęto brać pod uwagę kwestie związane z tworzeniem miejsc pracy, które pozytywnie oddziałują na bezpieczeństwo socjalne i jakość życia społeczeństw europejskich ${ }^{6}$.

Debata dotycząca inwestycji społecznych została podjęta w wyniku zmian zachodzących w europejskich społeczeństwach, także tych o charakterze kulturowym czy obyczajowym, takich m.in. jak: aktywność zawodowa kobiet, godzenie życia zawodowego i prywatnego, samotne rodzicielstwo, kryzys tradycyjnego modelu rodziny, i wynikających z nich nowych ryzyk społecznych ${ }^{7}$.

Propozycje nowego modelu polityki społecznej formułowane przez środowiska naukowe miały stanowić odpowiedź na wyżej zdiagnozowane wyzwania. Przede wszystkim skupiają się one na efektywnym inwestowaniu w rozwój umiejętności, wiedzy i kompetencji zasobów kapitału ludzkiego, niezbędnych do wzrostu zatrudnienia i podniesienia konkurencyjności gospodarki europejskiej. Poniżej zaprezentowane zostaną kluczowe założenia koncepcyjne inwestycji społecznych jako odpowiedzi w obszarze realizacji polityk publicznych na zdiagnozowane zagrożenia i ryzyka. Warto dodać, iż wprawdzie w różnym stopniu, ale odnoszą się one do wszystkich państw tworzących UE.

\footnotetext{
${ }^{4}$ Z. Długosz, Population ageing in Europe, „Procedia - Social and Behavioral Science” 19, 2011.

5 Report on Social Investment Pact - as a response to the crisis (2012/2003(INI)), European Parliament, Committee on Employment and Social Affairs, s. 5.

${ }^{6} \mathrm{~K}$. Kersbergen, A. Hemerijck, Two decades of change in Europe: The emergence of the social investment state, „Journal of Social Policy” 41, 2012, nr 3.

7 B. Bonoli, The politics of the new social policies. Providing coverage against new social risks in mature welfare state, „Policy \& Politics” 33, 2005, nr 1.
} 


\section{Koncepcyjne ujęcie inwestycji społecznych}

Trudno w jednoznaczny sposób wskazać, kiedy dokładnie sformułowane zostały pierwsze koncepcje inwestycji społecznych. Jeszcze przed kryzysem gospodarczym z $2008 \mathrm{r}$. w literaturze przedmiotu dotyczącej welfare state i systemów zabezpieczenia społecznego można było odnaleźć prace postulujące reformy polityki społecznej w kierunku zwiększenia produktywności zainwestowanych środków publicznych. Część autorów wskazuje, iż już w latach 90. ubiegłego stulecia pojawiały się propozycje reform w państwach dobrobytu, mające na celu przygotowanie społeczeństwa na nowe wyzwania związane z ryzykiem społecznym, konsolidacją fiskalną i budową gospodarki opartej na wiedzy ${ }^{8}$.

Inwestycyjny paradygmat polityki społecznej zakłada, iż stanowi ona nakład, który będzie podlegał zwrotowi w określonej perspektywie czasowej. Oznacza to, że ma ona charakter produktywny, ponieważ jej efektem ma być pomnożenie kapitału ludzkiego i społecznego. Zwrot z poczynionych inwestycji powinien mieć zarówno ekonomiczny, jak i społeczny wymiar?.

Inwestycje społeczne mają charakter aktywizacyjny. Instrumentem osiągania spójności społecznej oraz inkluzji ma być aktywizacja społeczno-zawodowa, która przynosi korzyści nie tylko beneficjentowi usług społecznych, ale szeroko rozumianemu otoczeniu, w którym funkcjonuje - od rodziny, poprzez społeczność lokalną, po państwo. W ten sposób krąg interesariuszy inwestycji społecznych ulega znacznemu rozszerzeniu w stosunku do beneficjentów tradycyjnej polityki społecznej opartej o transfery.

Kolejnym elementem koncepcji inwestycji społecznych jest szeroki zakres podmiotów pełniących rolę inwestora. W tradycyjnym modelu polityki społecznej opartej o transfery socjalne główną rolę odgrywają władze publiczne jako podmiot finansujący wsparcie społeczne. W modelu inwestycyjnym państwo traci monopol na realizację działań aktywizacyjnych, natomiast ważną rolę odgrywa sektor pozarządowy i prywatny, szczególnie w procesie dostarczania usług społecznych.

Formy wsparcia oparte o transfery publiczne tracą stopniowo na znaczeniu na rzecz działań opartych na edukacji, szkoleniach, transferze wiedzy i dobrych praktykach. Inwestycje społeczne promują także alternatywne i elastyczne formy zatrudnienia, jak np. zatrudnienie socjalne czy wolontariat, które umożliwiają podejmowanie aktywności zawodowej ludziom w różnej sytuacji rodzinnej i zawodowej. Tym samym grupy dotychczas defaworyzowane na rynku pracy mają większe szanse na podejmowanie aktywności zawodowej, którą mogą godzić z potrzebami rodzinnymi czy innymi rolami społecznymi, uniemożliwiającymi im tradycyjne formy partycypacji zawodowej. Takie grupy, jak np. samotni rodzice, osoby niepełnosprawne, osoby sprawujące opiekę nad osobami zależnymi, długotrwale bezrobotni, ludzie młodzi nieposiadający wystarczającego doświadczenia zawodowego, mogą wykorzystywać swój potencjał dzięki szerokim możli-

${ }^{8}$ F. Vandenbroucke, H. Hamerijck, B. Palier, The EU needs a social investment pact, „OSE Paper Series” maj 2011, nr 5, s. 5.

9 A. Brettschneider, On the way to social investment? The normative recalibration of the German welfare state, „German Policy Studies” 4, 2008, s. 26-29. 
wościom aktywizacji zawodowej. Aktywność w ramach rynku pracy ma być skutecznym instrumentem inkluzji społecznej, stanowiąc alternatywę dla świadczeń pieniężnych i rzeczowych w różnej postaci. Aktywizacja zawodowa grup defaworyzowanych ma na celu nie tylko zagwarantowanie dochodów, ale także ich społeczne upodmiotowienie. Zdaniem zwolenników nowego podejścia nie tylko prowadzi ono do wzrostu zatrudnienia, ale także zapewnia odpowiednią jakość zasobów pracy, niezbędnych w gospodarce opartej na wiedzy ${ }^{10}$.

Inwestycyjna polityka społeczna jest zorientowana na zaspokojenie potrzeb różnych grup społecznych. Beneficjentami polityki społecznej są nie tylko osoby pozostające w trudnej sytuacji, ubogie, wykluczone lub zagrożone ubóstwem i wykluczeniem społecznym. Adresatem działań proinwestycyjnych jest obywatel w całym cyklu swojego życia, niezależnie od wieku, płci czy sytuacji zawodowej. Stąd wśród beneficjentów inwestycyjnej polityki społecznej można odnaleźć zarówno dzieci, młodzież, jak i osoby starsze. Mają oni na poszczególnych etapach swojego życia zróżnicowane potrzeby, które wymagają odpowiednio zaprojektowanej polityki społecznej. Mimo silnej orientacji związanej z rynkiem pracy, każda jednostka jest traktowana jako zasób ekonomiczny i społeczny, posiadający określoną produktywność. Szczególne znaczenie mają działania na rzecz rozwoju dzieci, obejmujące programy opieki, a także nauczania, wychowania i profilaktyki zdrowotnej. Są one traktowane jako wyjątkowo cenny zasób społeczny, który charakteryzuje się najwyższym poziomem produktywności ${ }^{11}$.

Mimo że perspektywa inwestycyjna polityki społecznej uwzględnia zróżnicowane grupy społeczne jako jej potencjalnych i faktycznych beneficjentów, warto zauważyć, iż jest ona konstruowana w oparciu o rozpoznanie indywidualnych, specyficznych potrzeb jej odbiorców. Stąd zakres oferowanych przez nią usług jest niejako „szyty na miarę" i dostosowany do konkretnego adresata, przez co wzrasta prawdopodobieństwo jej efektywności w zaspokajaniu specyficznych potrzeb tego odbiorcy. Dostęp do równych i wysokiej jakości usług społecznych jest traktowany jako instrument zapewniający równe szanse wszystkim obywatelom i przyczyniający się do wyższego poziomu społecznego włączenia.

Przyjęcie prousługowej optyki w polityce społecznej ma swoje konsekwencje dla redefinicji roli państwa w procesie jej realizacji. Nadal pozostaje ono głównym „inwestorem” w rozwój usług o charakterze społecznym, ale nie jest już monopolistą w tej dziedzinie. Ta zmiana związana jest ze wzrostem znaczenia innych sektorów: społecznego i prywatnego jako dostarczycieli usług odpowiedniej jakości, nie tylko ze względu na wyzwania natury fiskalnej, ale także wyższą efektywność w zaspokajaniu zindywidualizowanych potrzeb społecznych. Wskazuje się na rosnące znaczenie sektora ekonomii społecznej we wdrażaniu inwestycji społecznych. Sektor ten jest tworzony przez podmioty, które działając w sposób komercyjny, realizują określone cele społeczne, chociażby dotyczące

10 S. Nelson, Do Social Investment Policies Produce More and Better Jobs?, [w:] Towards a Social Investment Welfare State?, red. N. Morel, B. Palier, J. Palme, Bristol 2011.

11 C. Deeming, P. Smyth, Social investment after neoliberalism: Policy paradigms and political platforms, „Journal of Social Policy” 44, 2015. 
walki z wykluczeniem społecznym czy bezrobociem ${ }^{12}$. W krajach Europy Zachodniej odnotowywany jest wzrost znaczenia podmiotów niepublicznych w realizacji usług społecznych - szczególnie organizacji pozarządowych, spółdzielni czy firm prywatnych ${ }^{13}$. Wskazuje się, iż są one zdolne do świadczenia usług nie tylko wysokiej jakości, ale także konkurencyjnych pod względem kosztowym ${ }^{14}$, co obniża finalny nakład niezbędny do realizacji planowanych inwestycji.

\section{Aktywność Komisji Europejskiej na rzecz wdrożenia paradygmatu inwestycyjnego w politykach społecznych państw członkowskich}

Powyżej zdefiniowane wyzwania doprowadziły do sytuacji, w której na forum UE przyjęto założenie, iż sytuacja demograficzna, kryzys ekonomiczny oraz stale kurczące się publiczne zasoby finansowe wymagają niezbędnych reform systemów socjalnych w państwach członkowskich. Głównym celem działań KE zorientowanych na wdrożenie paradygmatu inwestycyjnego do polityk społecznych państw członkowskich jest adaptacja systemów ochrony socjalnej do zmian społeczno-ekonomicznych, scharakteryzowanych w pierwszej części artykułu. Jednym z celów traktatowych UE jest spójność społeczna, gospodarcza i terytorialna, a zmiany demograficzne i gospodarcze mogą stanowić przeszkodę w jej osiąganiu. Aktualna strategia rozwoju UE Europa 2020 bazuje na zasadniczym priorytecie, którym jest inteligentny, zrównoważony i sprzyjający włączeniu społecznemu wzrost. Ma on zostać osiągnięty w roku 2020 poprzez określone działania, które w wymiarze społecznym mają na celu:

— wzrost wskaźnika aktywności zawodowej osób w wieku 20-64 do 75\%;

- redukcję liczby osób młodych przedwcześnie kończących edukację do poziomu poniżej 10\%;

- wzrost liczby osób z wyższym wykształceniem do 40\%;

— zmniejszenie liczby osób zamieszkujących UE zagrożonych ubóstwem społecznym i wykluczeniem społecznym o $20 \mathrm{mln}^{15}$.

Realizacja wyżej zdefiniowanych celów ma odbywać się dzięki wdrożeniu dwóch inicjatyw przewodnich: Europejskiej platformy współpracy w zakresie walki z ubóstwem i wykluczeniem społecznym oraz Programu na rzecz Nowych Umiejętności i Zatrudnienia ${ }^{16}$.

12 I. Nasioulas, Social economy: A viable alternative?, Hellenic Foundation for European and Foreign Policy (ELIAMEP), „Policy Paper” nr 26, 2015; M. Szebehely, G.B. Trydegård, Home care for older people in Sweden: A universal model in transition, „Health and Social Care in the Community” 20, 2012, nr 3.

13 P. Bernard, G. Boucher, Institutional competitiveness, social investment, and welfare regime, „Regulation \& Governance" 1, 2007.

14 R. Mahon et al., Convergent care regimes? Childcare arrangements in Australia, Canada, Finland and Sweden, „Journal of European Social Policy” 22, 2012, nr 4.

15 Europa 2020. Strategia na rzecz inteligentnego i zrównoważonego rozwoju sprzyjającego włączeniu społecznemu, KOM (2010) 2020 wersja ostateczna, Komisja Europejska, Bruksela, 3.3.2010, s. 12.

${ }^{16}$ Ibidem, s. 6. 
W 2013 r. KE opublikowała wytyczne pod nazwą Social Investement Package, dotyczące pożądanych kierunków zmian od tradycyjnego modelu polityki społecznej do paradygmatu inwestycyjnego. Polityka społeczna $\mathrm{w}$ wariancie inwestycyjnym ma $\mathrm{w}$ opinii KE przyczyniać się do jednoczesnej realizacji dwóch celów: ochrony obywateli przed ubóstwem oraz wspierania wzrostu gospodarczego ${ }^{17}$. Inwestycje społeczne stwarzają państwom członkowskim, z jednej strony, możliwość wdrożenia strategii aktywizacji społecznej obywateli, z drugiej zaś - bardziej efektywne wydatkowanie środków publicznych na realizację powyższego celu ${ }^{18}$. Pakiet zawiera szereg wytycznych dla państw członkowskich dotyczących: bardziej efektywnego gospodarowania budżetem socjalnym na rzecz zapewnienia lepszej ochrony socjalnej, skutecznej polityki rozwoju potencjału ludzi $\mathrm{w}$ celu ich aktywizacji społeczno-zawodowej, tworzenia zintegrowanego systemu usług dla obywateli w całym cyklu ich życia, redukcji działań interwencyjnych na rzecz wyprzedzających, mających na celu zapobieganie wystąpieniu problemów społecznych, a także inwestowania w rozwój dzieci i młodzieży w celu poprawy ich szans w dorosłym życiu ${ }^{19}$.

$\mathrm{W}$ podobnym tonie przygotowany został zrewidowany dokument Wytyczne w sprawie zatrudnienia, który postuluje aktywizację i poprawę dostępu do usług jako dwa elementy: wsparcie uczestnictwa jednostek w rynku pracy oraz inwestowanie w rozwój kapitału ludzkiego w całym cyklu życia człowieka ${ }^{20}$. KE kładzie szczególny nacisk na rozwój, ale też wykorzystanie potencjału wszystkich grup, które dzięki odpowiednio prowadzonej polityce inwestycyjnej mogą być użyteczne na rynku pracy i w społeczeństwie na każdym etapie swojego życia.

Warto zauważyć, iż oba wcześniej przywołane dokumenty stanowią tzw. miękkie prawo i nie mają charakteru obligatoryjnego. Oznacza to, że państwa członkowskie mają pełną dowolność co do zakresu i sposobów wdrażania tak sformułowanych wytycznych. Zarządzanie kwestiami społecznymi takimi, jak edukacja, ochrona socjalna, szkolenia, polityka zatrudniania w UE, odbywa się w oparciu o metodę otwartej koordynacji, która w żaden sposób nie obliguje państwa członkowskiego do zmiany istniejącego lub wprowadzania nowego prawa ${ }^{21}$. Zatem można się spodziewać, iż w przypadku części państw same zachęty mogą okazać się niewystarczające do upowszechnienia w praktyce politycznej perspektywy inwestycji.

Chociaż wytyczne nie mają charakteru obligatoryjnego dla państw członkowskich, KE dysponuje szeregiem instrumentów mogących zmobilizować państwa do wdrażania zaproponowanych kierunków działań. Pierwszym z nich jest Europejski Fundusz Spo-

17 J. Przywojska, Polityka społeczna miasta, [w:] EkoMiasto\#Społeczeństwo. Zrównoważony, inteligentny i partycypacyjny rozwój miasta, red. A. Nowakowska, Z. Przygodzki, A. Rzeńca, Łódź 2016, s. 54.

18 C. Borzaga, R. Bodinia, What to make of social innovation? Towards a framework for policy development, „Social Policy and Society” 1, 2014, nr 3.

19 C. Dheret, L. Fransen, Social investment first! A precondition for a modern social Europe, „European Policy Centre Issue Paper" 82, marzec 2017, s. 31.

20 Ibidem, s. 30.

${ }^{21}$ M. Heidenreich, The Open Method of Coordination: A Pathway to the Gradual Transformation of National Employment and Welfare Regimes, [w:] Changing European Employment and Welfare Regimes. The Influence of the Open Method of Coordination on National Reforms, red. idem, J. Zeitlin, London 2009, s. 10-36. 
łeczny (EFS) jako instrument finansowy wsparcia aktywnej polityki rynku pracy na poziomie narodowym i regionalnym. Państwa otrzymujące środki z EFS są zobligowane do opracowania krajowych strategii zatrudniania i wdrażania tych operacji, które wpisują się w paradygmat inwestycyjny polityki społecznej. Wdrażanie EFS w latach 2014-2020 oparte jest na tematycznych celach, wśród których pojawiają się: zwalczanie ubóstwa i wykluczenia społecznego, promowanie zatrudnienia i wsparcie mobilności siły roboczej, inwestowanie w edukację, rozwój umiejętności i uczenie się przez całe życie ${ }^{22}$.

Inną zachętą natury finansowej jest Program na rzecz Zatrudnienia i Innowacji Społecznych realizowany przez KE od $2014 \mathrm{r}$. Jego celem jest promowanie wysokiego poziomu zatrudnienia, gwarantowanie odpowiedniej i godnej ochrony socjalnej, zwalczanie wykluczenia społecznego i ubóstwa oraz poprawa warunków pracy. Wartość programu wynosi niecały miliard euro, stąd państwa członkowskie nie wykazują zbyt dużego zaangażowania w pozyskanie środków zewnętrznych. Wśród osi priorytetowych na największą uwagę zasługuje oś trzecia: dostęp do finansowania dla grup w trudnej sytuacji i mikroprzedsiębiorstw oraz przedsiębiorczość społeczna. Chociaż pod względem dedykowanego budżetu obejmuje ona $21 \%$ wszystkich nakładów ${ }^{23}$, tworzy systemowe podwaliny pod zmiany związane ze wzrostem udziału sektora ekonomii społecznej w Europie.

Jak wskazuje raport opracowany przez Europejską Sieć Polityki Społecznej, nowy paradygmat w polityce społecznej zyskuje różną popularność w państwach członkowskich. W raporcie wskazano także negatywny wpływ postulowanej przez KE konsolidacji fiskalnej na rozwój inwestycji społecznych. Powoduje ona, iż programy o charakterze inwestycyjnym są zastępowane przez bardziej skonsolidowane instrumenty o charakterze akcyjnym oraz pasywne krótkoterminowe instrumenty. Raport wskazuje także na przyczyny zróżnicowania tempa wdrażania inwestycji społecznych w państwach członkowskich, do których zaliczają się nie tylko te natury politycznej, ale także znajomość założeń nowego konceptu $\mathrm{w}$ systemach instytucjonalnych państw. Ponadto państwa wdrażają tylko wybrane elementy strategii inwestycyjnych, co powoduje, że rezultaty są słabsze niż w przypadku implementacji podejścia inwestycyjnego w polityce społecznej danego kraju w jak największym zakresie ${ }^{24}$.

\section{Wybrane studia przypadków przykładowych inwestycji społecznych realizowanych w Europie}

Promocja inwestycyjnej polityki społecznej przez UE skutkuje realizacją wielu inicjatyw spełniających kryteria inwestycji społecznych w państwach europejskich na poziomie krajowym, regionalnym i lokalnym. Chociaż motywem przewodnim koncepcji jest

22 C. Dheret, L. Fransen, op. cit., s. 34.

23 Europejski Program na rzecz Zatrudnienia i Innowacji Społecznych (EaSI), Komisja Europejska, http:// ec.europa.eu/social/main.jsp?langId=pl\&catId=1081 (dostęp: 30 czerwca 2017).

24 D. Bouget et al., Social investment in Europe - a study of national policies, European Commission, European Social Policy Network (ESPN) 2015, s. 12. 
aktywizacja obywateli w obszarze rynku pracy, zaznaczyć należy, iż wszelkie działania podnoszące produktywność jednostek, ale także rozwiązania prawne, systemowe i finansowe wspierające rozwój kapitału ludzkiego i społecznego, można określić mianem inwestycji społecznych.

Interesującą, a jednocześnie innowacyjną inicjatywą o charakterze inwestycyjnym jest utworzenie w Wielkiej Brytanii w 2012 r. instytucji finansowej Big Society Capital (BSC). Została ona uruchomiona w celu rozwoju rynku inwestycji społecznych w Wielkiej Brytanii poprzez udzielanie zwrotnego wsparcia finansowego na rzecz organizacji pozarządowych, zainteresowanych wdrażaniem inwestycyjnych działań o charakterze społecznym. Warto dodać, iż Wielka Brytania posiada dobrze rozwinięty, działający na zasadach komercyjnych, sektor ekonomii społecznej. Uruchomienie BSC miało na celu dalsze wzmocnienie sektora prywatnego i pozarządowego w realizacji działań o charakterze społecznym. Chociaż inicjatorem i głównym fundatorem przedsięwzięcia był rząd brytyjski, organizacja ta jest od niego niezależna. Początkowy kapitał na funkcjonowanie instytucji został pozyskany dzięki przekazanym przez rząd środkom, pochodzącym $\mathrm{z}$ „uśpionych” rachunków bankowych i kas mieszkaniowych. W 2008 r. przyjęta została ustawa umożliwiająca przekazywanie na rzecz BSC takich zasobów finansowych, które pozostawały na rachunkach nieaktywnych co najmniej przez 15 lat $^{25}$. 40\% finansowania przedsięwzięcia zostało zagwarantowane przez cztery największe banki komercyjne Wielkiej Brytanii: Barclays, Lloyds, HSBC oraz Royal Bank of Scotland, które podczas kryzysu ekonomicznego korzystały z pomocy publicznej. Warto dodać, iż banki te posiadają jedynie $20 \%$ głosów w procedurze podejmowania decyzji, co ma ułatwić realizację celów społecznych przez tę instytucję $e^{26}$.

BSC skupia się na wsparciu projektów innowacyjnych, które mają na celu rozwiązywanie problemów społecznych występujących szczególnie wśród grup wykluczonych bądź zagrożonych wykluczeniem społecznym. Głównymi obszarami tematycznymi działania BSC są: edukacja, zatrudnienie, inkluzja społeczna, rodzina, zdrowie i opieka społeczna oraz mieszkalnictwo ${ }^{27}$.

BSC należy uznać za inicjatywę innowacyjną i inwestycyjną jednocześnie. Jest pierwszą tego typu instytucją w skali światowej, wspierającą podmioty prowadzące działania proinwestycyjne. Poprzez swoją aktywność tworzy finansowe podstawy dla wdrażania inwestycji społecznych, ale na zasadach komercyjnych. Zapewnia dywersyfikację źródeł finansowania inicjatyw poprzez zaangażowanie zasobów sektora bankowego. Wymiar inwestycyjny dotyczy jego zaangażowania na rzecz wspierania przedsiębiorstw społecz-

${ }^{25} \mathrm{M}$. Jetmar, Overview of attitudes and financial instruments for social economy in NBFSE countries and case studies on selected practice of support, The Network for Better Future of Social Economy (NBFSE) Strand „Financial instruments and mechanisms of funds' allocation to Social Economy”, Prague 2012, s. 33-34, http://www.ekonomiaspoleczna.pl/files/ekonomiaspoleczna.pl/public/_MRR_Better_Future/BFSE_FI_ Product1-Overview_case_studies.pdf (dostęp: 27 czerwca 2017).

${ }^{26}$ E. Janikowska, Big Society Capital - na rzecz Innowacji Społecznych, http://alebank.pl/big-societycapital-na-rzecz-innowacji-spoecznych/?id=15743\&catid=358 (dostęp: 30 czerwca 2017).

27 Big Society Capital. Our Strategy for the Next Three Years, maj 2014, s. 13, https://www.bigsocietycapital.com/sites/default/files/Strategy\%20v5.pdf (dostęp: 2 lipca 2016). 
nych, które pozyskują w ten sposób środki na realizację własnych projektów i pomysłów. Ma ono charakter pożyczki lub udziału kapitałowego, a nie dotacji, co oznacza że spłacane przez grantobiorców środki będą inwestowane w kolejne przedsięwzięcia. Chociaż pojawiają się głosy wskazujące na polityczny rodowód koncepcji „wielkiego społeczeństwa" i instytucji finansowej mającej na celu urzeczywistnienie tej wizji ${ }^{28}$, trudno odmówić oryginalności tej inicjatywie. Może ona stanowić inspirację w szczególności dla tych państw, w których sektor przedsiębiorczości społecznej jest w fazie tworzenia się oraz wypracowywania modelu swojego funkcjonowania, finansowania i rozwoju.

Drugim $\mathrm{z}$ analizowanych studiów przypadków rozwiązań inwestycyjnych w polityce społecznej jest Rządowy Program na rzecz Aktywizacji Osób Starszych ASOS. Wybór tego studium przypadku podyktowany został trzema względami. Po pierwsze, jego realizacja wynika z procesów europeizacji, a dokładnie - wpływu ustanowionego w $2012 \mathrm{r}$. Europejskiego Roku Aktywności Osób Starszych i Solidarności Międzypokoleniowej w UE ${ }^{29}$ na wzrost świadomości decydentów i społeczeństwa w zakresie problemów i potrzeb ludzi starszych. Po drugie, ASOS jest pierwszą w Polsce inicjatywą o charakterze rządowym, dotyczącą aktywizacji społecznej ludzi starszych. Dotychczasowe inicjatywy na rzecz osób starszych ograniczały się do działań stricte socjalnych bądź aktywizacyjnych na rynku pracy. Po trzecie, program realizowany jest w tej części Europy, gdzie paradygmat inwestycyjny w polityce społecznej jeszcze się nie upowszechnił, co, jak wskazuje przykład ASOSa, nie oznacza, iż jest on kompletnie nieobecny w praktyce działania państwa.

ASOS jest realizowany w dwóch edycjach 2012-2013 oraz 2014-2020. Celem głównym programu w ramach obydwu edycji jest poprawa jakości i poziomu życia osób starszych, dla godnego starzenia się, poprzez aktywność społeczną. Jest on skierowany do osób w wieku 60+, których liczba w Polsce, w związku z wyżem demograficznym lat 50. ubiegłego stulecia, dynamiczne wzrasta, a które po zakończeniu aktywności zawodowej zainteresowane są zaangażowaniem w życie społeczne i wykorzystaniem swojego potencjału wiedzy, doświadczenia życiowego czy umiejętności. Program obejmuje cztery priorytety:

- edukację społeczną;

- aktywność społeczną promującą integrację wewnątrz- i międzypokoleniową;

- partycypację osób starszych;

— rozwój systemu usług na rzecz osób starszych ${ }^{30}$.

28 J. Daggers, A. Nicholls, Big Society Capital - The World's First Social Investment Wholesale Bank, październik 2016, s. 4, https://www.sbs.ox.ac.uk/sites/default/files/Skoll_Centre/Images/Research/BSCCase-Study.pdf (dostęp: 30 czerwca 2017).

29 Decyzja Parlamentu Europejskiego i Rady nr 940/2011/UE z dnia 14 września 2011 r. w sprawie Europejskiego Roku Aktywności Osób Starszych i Solidarności Międzypokoleniowej 2012, Dz. Urz. UE L246, 23.9.2011.

30 Rządowy Program na rzecz Aktywności Społecznej Osób Starszych na lata 2014-2020, Ministerstwo Pracy i Polityki Społecznej, 2014, s. 10, https://www.mpips.gov.pl/gfx/mpips/userfiles/_public/1_NOWA\%20 STRONA/Seniorzy/Program\%20ASOS\%202014-2020.pdf (dostęp: 23 października 2017). 
Realizacja programu ma przyczynić się do wydłużenia społecznej produktywności osób starszych, która w ich wypadku oznacza zaangażowanie $\mathrm{w}$ opiekę nad dziećmi czy innymi osobami zależnymi, pomoc rodzinie, sąsiadom, znajomym, wolontariat czy prace domowe. Jest to związane $\mathrm{z}$ dążeniem do maksymalnego wydłużenia czasu trwania użyteczności społecznej seniorów ${ }^{31}$ oraz umożliwieniem im spełniania różnych ról w życiu publicznym.

Chociaż działania aktywizacyjne dla seniorów podejmowane są w ramach ASOSa na poziomie krajowym, to realizacja operacji przebiegła na lokalnym szczeblu zarządzania. Innowacyjność tego rozwiązania polega na fakcie, iż proces implementacji programu bazuje na zasobach organizacji pozarządowych, a efekty uzależnione są od jakości proponowanych projektów. Ponadto ASOS jako program o charakterze inwestycyjnym wskazuje na osoby starsze jako zasób społeczny, który może być wykorzystany także do kreowania wzrostu gospodarczego w ramach tzw. srebrnej gospodarki.

\section{Podsumowanie}

W niniejszym artykule zaprezentowane zostało stanowisko UE wobec nowego paradygmatu polityki społecznej, jakim są inwestycje społeczne. Z przeprowadzonej analizy wynika, że temat inwestycji społecznych ma charakter wielowymiarowy i pojawił się jako odpowiedź na nieskuteczność rozwiązań tradycyjnej polityki społecznej w obszarze zatrudniania, inkluzji społecznej i kryzysu demograficznego. Jak wskazują badacze podejmujący problematykę inwestycji społecznych, ich wyjątkowość w stosunku do wcześniej oferowanych rozwiązań polega na rozszerzeniu katalogu beneficjentów o różne grupy wiekowe, społeczne i zawodowe na wszystkich etapach życia prywatnego i zawodowego. Ponieważ polityka inwestycyjna ma silnie produktywistyczny wymiar, nacisk kładzie na korzyści, jakie dzięki jej realizacji może osiągać społeczeństwo, państwo i gospodarka.

Warto na zakończenie dodać, iż nowy paradygmat budzi nie tylko entuzjazm, ale można także spotkać stanowiska krytyczne wobec jego założeń artykułowane przez część badaczy czy działaczy społecznych. Kontrowersje, które towarzyszą wdrażaniu tego nowego paradygmatu, mają różnoraki charakter: od etycznych, po te dotyczące pomiarów efektywności podejścia inwestycyjnego w rozwiązywaniu problemów społecznych i generowaniu korzyści społecznych. Ponieważ część nakładów finansowych zainwestowanych w rozwój np. dzieci czy młodzieży może się zwrócić dopiero w perspektywie średnio- lub długookresowej, trudno będzie oceniać rezultaty tej polityki na bieżąco. Brak możliwości weryfikacji w perspektywie krótkookresowej sprawia, że rośnie ryzyko związane z nieefektywnym wydatkowaniem zasobów publicznych, które mogą nie przynieść spodziewanych korzyści. Z powyższą kwestią związany jest dodatkowo problem

31 P. Szukalski, Aktywność zawodowa, [w:] Aspekty medyczne, psychologiczne, socjologiczne i ekonomiczne starzenia się ludzi w Polsce (PolSenior), red. P. Błędowski, M. Mossakowska, A. Więcek, Poznań 2013, s. 407, http://212.87.21.2/polsenior/sites/polsenior.iimcb.gov.pl/files/file/monografia/monografiaPolSenior. pdf (dostęp: 24 czerwca 2017). 
ewaluacji, która bezwzględnie powinna być prowadzona w celu weryfikacji osiąganych efektów. W przypadku inwestycji społecznych wyzwanie stanowi wybór metodologii prowadzenia badań, który nie jest oczywisty w przypadku szacowania korzyści społecznych z poczynionych inwestycji.

Pojawiają się wprawdzie różne metody obliczania wzajemnych proporcji ponoszonych nakładów do osiąganych zysków w postaci chociażby kalkulatora kosztów zaniechania $^{32}$ czy stopy społecznego zwrotu $\mathrm{z}$ inwestycji (ang. social return on investement) ${ }^{33}$, jednak wybór metodologii determinuje wynik dotyczący ich efektywności ${ }^{34}$. Problem stanowi fakt, że metody te nie biorą pod uwagę ryzyka oraz nie wskazują na stopień oddziaływania społecznego inwestycji ${ }^{35}$. Są one szczególnie ważne z perspektywy takiej instytucji jak KE, która stale poszukuje dowodów na pozytywny wpływ inwestycji społecznych na rozwój społeczny i gospodarczy Europy. Wynika to z faktu, iż realizacja paradygmatu inwestycyjnego związana jest z ponoszeniem wysokich nakładów, których nie sposób odzyskać w krótkiej perspektywie czasowej ${ }^{36}$. W związku z rosnącą presją na oszczędności w wydatkach sektora publicznego wydatkowanie pieniędzy publicznych musi mieć uzasadnienie $\mathrm{w}$ wysokim poziomie efektywności tej polityki.

UE postrzega inwestycje społeczne nie tylko jako sposób na podniesienie produktywności kapitału społecznego, ale także jako narzędzie walki z ubóstwem i wykluczeniem społecznym. Natomiast część autorów kontrargumentuje, iż rozwiązanie to ma wręcz negatywny wpływ na poziom spójności społecznej i inkluzję ${ }^{37}$. Wynika to przede wszystkim z faktu ograniczenia transferów socjalnych na rzecz osób pozostających poza rynkiem pracy, a także wybranych priorytetów prowadzonej polityki inwestycyjnej. Reorientacja wydatków publicznych ze wsparcia bezpośredniego w kierunku aktywizacji, przy jednoczesnej redukcji ich poziomu, może przyczyniać się do powiększania strefy ubóstwa.

Ostatni ze wskazanych obszarów krytyki nowej koncepcji odnosi się do kwestii etycznych związanych z wdrożeniem inwestycyjnego podejścia. Badacze krytyczni wobec nowego paradygmatu wskazują, iż koncentracja na produktywności jednostki powoduje, że inwestycje społeczne prowadzą do uprzedmiotowienia jednostki, której wartość jest szacowana z perspektywy potrzeb rynku pracy i gospodarki. Zatem inwestycje społeczne mają charakter selektywny i skierowane są do tych grup, w których stopa zwrotu z zainwestowanych zasobów będzie największa ${ }^{38}$. Tym samym umacniają one zróżnicowane szanse na rozwój jednostek w społeczeństwie.

32 P. Błędowski, P. Kubicki, Kalkulator społeczny jako element projektu „Kalkulator kosztów zaniechania” w lokalnej polityce społecznej, „Polityka Społeczna” 2014, nr 3, s. 2-5.

33 D. Moroń, M. Klimowicz, Zastosowanie stopy społecznego zwrotu $z$ inwestycji (SROI) jako wskaźnika mierzenia efektywności projektów społecznych, „Wrocławskie Studia Politologiczne” 21, 2016.

34 M.J. Roy, N. McHugh, C.H. O'Connor, Social innovation: Worklessness, welfare and well-being, „Social Policy and Society" 13, 2014, nr 3.

35 E. Carter, A. Whitworth, Creaming and parking in quasi-marketised welfare-to-work schemes: Designed out of or designed in to the UK work programme?, „Journal of Social Policy” 44, 2015, nr 2.

36 S. Nelson, op. cit., s. 13.

37 P. Taylor-Gooby, New Risks and Social Change, [w:] New Risks, New Welfare: The Transformation of the European Welfare State, red. idem, London 2004.

38 P. Michoń, op. cit. s. 101-102. 
UE podejmuje wysiłki w celu upowszechnienia nowego paradygmatu w państwach europejskich. Obecnie paradygmat ten cieszy się zróżnicowanym zainteresowaniem wśród państw, niemniej jednak część krajów już wcześniej rozpoczęła wdrażanie paradygmatu inwestycyjnego w realizacji krajowych polityk społecznych. Dotyczy to głównie państw skandynawskich, które skutecznie łączą założenia podejścia inwestycyjnego z tradycyjnymi formami ochrony socjalnej, oraz Wielkiej Brytanii i Niderlandów, gdzie polityka inwestycyjna ma bardziej prorynkowy charakter, oparty na aktywnym udziale sektora ekonomii społecznej i podmiotów prywatnych w realizacji usług społecznych.

Państwa Europy Środkowo-Wschodniej oraz Południowej są w mniejszym stopniu zaangażowane we wdrożenie nowego paradygmatu, co nie przekreśla faktu, iż w systemach tych krajów także funkcjonują instrumenty i formy wsparcia noszące znamiona inwestycji społecznych. Jednym z nich jest chociażby Rządowy Program na rzecz Aktywizacji Społecznej Osób Starszych ASOS, scharakteryzowany w niniejszym artykule. Mimo pojawiających się stanowisk krytycznych wobec inwestycyjnego paradygmatu polityki społecznej, można spodziewać się stopniowego wzrostu jej znaczenia jako odpowiedzi na wyzwania społeczne i gospodarcze w UE.

\section{Bibliografia}

Bernard P., Boucher G., Institutional competitiveness, social investment, and welfare regime, „Regulation \& Governance" 1, 2007.

Big Society Capital. Our Strategy for the Next Three Years, maj 2014, s. 13, https://www.bigsocietycapital.com/ sites/default/files/Strategy\%20v5.pdf (dostęp: 2 lipca 2016).

Błędowski P., Kubicki P., Kalkulator społeczny jako element projektu „Kalkulator kosztów zaniechania” w lokalnej polityce społecznej, „Polityka Społeczna” 2014, nr 3.

Bonoli G., The politics of the new social policies. Providing coverage against new social risks in mature welfare state, „Policy \& Politics” 33, 2005, nr 1.

Borzaga C., Bodinia R., What to make of social innovation? Towards a framework for policy development, „Social Policy and Society” 13, 2014, nr 3.

Bouget D. et al., Social investment in Europe - a study of national policies, European Commission, European Social Policy Network (ESPN) 2015.

Brettschneider A., On the way to social investment? The normative recalibration of the German welfare state, „German Policy Studies” 4, 2008.

Carter E., Whitworth A., Creaming and parking in quasi-marketised welfare-to-work schemes: Designed out of or designed in to the UK work programme?, „Journal of Social Policy” 44, 2015, nr 2.

Cieplewska-Kowalik A., Znaczenie rozwoju powszechnego systemu usług opieki i edukacji przedszkolnej w Polsce. W stronę nowego kontraktu społecznego wobec współczesnych wyzwań demograficznych, ekonomicznych $i$ społecznych, „Prace Naukowe Uniwersytetu Ekonomicznego we Wrocławiu” nr 292, 2013.

Daggers J., Nicholls A., Big Society Capital — The World's First Social Investment Wholesale Bank, październik 2016, Saïd Business School Case, https://www.sbs.ox.ac.uk/sites/default/files/Skoll_Centre/Images/Research/BSC-Case-Study.pdf (dostęp: 30 czerwca 2017).

Decyzja Parlamentu Europejskiego i Rady nr 940/2011/UE z dnia 14 września 2011 r. w sprawie Europejskiego Roku Aktywności Osób Starszych i Solidarności Międzypokoleniowej 2012, Dz. Urz. UE L246, 23.9.2011.

Deeming C., Smyth P., Social investment after neoliberalism: Policy paradigms and political platforms, „Journal of Social Policy" 44, 2015. 
Dheret C., Fransen L., Social investment first! A precondition for a modern social Europe, „European Policy Centre Issue Paper" 82, marzec 2017.

Długosz Z., Population ageing in Europe, „Procedia — Social and Behavioral Science” 19, 2011.

Europa 2020. Strategia na rzecz inteligentnego i zrównoważonego rozwoju sprzyjajacego włączeniu społecznemu, KOM (2010) 2020 wersja ostateczna, Komisja Europejska, Bruksela, 3.3.2010.

Europejski Program na rzecz Zatrudnienia i Innowacji Społecznych (EaSI), Komisja Europejska, http://ec.europa. eu/social/main.jsp?langId=pl\&catId=1081 (dostęp: 30 czerwca 2017).

Grewiński M., Inwestycyjna polityka społeczna. Nowy paradygmat państwa dobrobytu, [w:] Praca socjalna wobec wyzwań współczesności, t. 1, red. E. Bojanowska, M. Kawińska, Wydawnictwo Kontrast, Warszawa 2015.

Grewiński M., Inwestycyjna polityka społeczna oparta na ustugach. W kierunku nowego modelu welfare state?, [w:] Innowacyjna polityka społeczna, red. idem, A. Karwacki, Wyższa Szkoła Pedagogiczna im. Janusza Korczaka, Warszawa 2015.

Heidenreich M., The Open Method of Coordination: A Pathway to the Gradual Transformation of National Employment and Welfare Regimes, [w:] Changing European Employment and Welfare Regimes. The Influence of the Open Method of Coordination on National Reforms, red. idem, J. Zeitlin, Routledge, London/ /New York 2009.

Iglicka K., Demograficzne wyzwania dla rynków pracy, polityk społecznych i bezpieczeństwa Europy Środkowej, „Polityka Społeczna” nr 1, 2013.

Janikowska, Big Society Capital - na rzecz Innowacji Społecznych, http://alebank.pl/big-society-capital-narzecz-innowacji-spoecznych/?id=15743\&catid=358 (dostęp: 30 czerwca 2017).

Jetmar M., Overview of attitudes and financial instruments for social economy in NBFSE countries and case studies on selected practice of support, The Network for Better Future of Social Economy (NBFSE) Strand „Financial instruments and mechanisms of funds' allocation to Social Economy”, Prague 2012, http:// www.ekonomiaspoleczna.pl/files/ekonomiaspoleczna.pl/public/_MRR_Better_Future/BFSE_FI_Product1-Overview_case_studies.pdf (dostęp: 27 czerwca 2017).

Kersbergen K., Hemerijck A., Two decades of change in Europe: The emergence of the social investment state, „Journal of Social Policy” 41, 2012, nr 3.

Mahon R. et al., Convergent care regimes? Childcare arrangements in Australia, Canada, Finland and Sweden, „Journal of European Social Policy” 22, 2012, nr 4.

Michoń P., Dzieciństwo w Bullerbyn czy z tiger mothers? Bycie dzieckiem a stawanie się szczęśliwym dorostym - zastrzeżenia wobec stosowania perspektywy inwestycji społecznych w polityce społecznej, „Przegląd Socjologiczny" 63, 2014, z. 4.

Moroń D., Klimowicz M., Zastosowanie stopy społecznego zwrotu z inwestycji (SROI) jako wskaźnika mierzenia efektywności projektów społecznych, „Wrocławskie Studia Politologiczne” 21, 2016.

Nasioulas I., Social economy: A viable alternative?, Hellenic Foundation for European and Foreign Policy (ELIAMEP), „Policy Paper” nr 26, 2015.

Nelson S., Do Social Investment Policies Produce More and Better Jobs?, [w:] Towards a Social Investment Welfare State?, red. N. Morel, B. Palier, J. Palme, Policy Press, Bristol 2011.

Przywojska J., Polityka społeczna miasta, [w:] EkoMiasto\#Społeczeństwo. Zrównoważony, inteligentny i partycypacyjny rozwój miasta, red. A. Nowakowska, Z. Przygodzki, A. Rzeńca, Wydawnictwo Uniwersytetu Łódzkiego, Łódź 2016.

Report on Social Investment Pact - as a response to the crisis (2012/2003(INI)), European Parliament, Committee on Employment and Social Affairs.

Roy M.J., McHugh N., O'Connor C.H., Social innovation: Worklessness, welfare and well-being, „Social Policy and Society" 13, 2014, nr 3.

Rządowy Program na rzecz Aktywności Społecznej Osób Starszych na lata 2014-2020, Ministerstwo Pracy i Polityki Społecznej, 2014, https://www.mpips.gov.pl/gfx/mpips/userfiles/_public/1_NOWA\%20STRONA/Seniorzy/Program\%20ASOS\%202014-2020.pdf (dostęp: 23 października 2017). 
Szebehely M., Trydegård G.B., Home care for older people in Sweden: A universal model in transition, „Health and Social Care in the Community" 20, 2012, nr 3.

Szukalski P., Aktywność zawodowa, [w:] Aspekty medyczne, psychologiczne, socjologiczne i ekonomiczne starzenia się ludzi w Polsce (PolSenior), red. P. Błędowski, M. Mossakowska, A. Więcek, Termedia Wydawnictwa Medyczne, Poznań 2013, http://212.87.21.2/polsenior/sites/polsenior.iimcb.gov.pl/files/file/ monografia/monografiaPolSenior.pdf (dostęp: 24 czerwca 2017).

Taylor-Gooby P., New Risks and Social Change, [w:] New Risks, New Welfare: The Transformation of the European Welfare State, red. idem, Oxford University Press, London 2004.

Vandenbroucke H., Hamerijck A., Palier B., The EU needs a social investment pact, „OSE Paper Series” maj 2011, nr 5.

Wiktorska-Święcka A. et al., Inwestycje społeczne jako nowy paradygmat polityk publicznych w Unii Europejskiej, Wydawnictwo Naukowe Scholar, Warszawa 2017.

\section{European Union's position towards social investment paradigm}

Keywords: social investment, social policy, human capital, social capital, social activation, evaluation

Summary

In this paper the author analyses the new social investment paradigm which has been applied by the European Union since several years. The main aim is to present the attitude and activities of the European Commission in order to implement this new paradigm in the member states' social policies. The reasons of establishment the investment paradigm in social development policy are explained. The main elements of the social investment concept as: activisation, productivity, social services orientation, combating social exclusion are described. The economic, social, demographic and cultural changes in Europe during the last twenty years and their impact on new social risks development are considered. The article also contains the characteristics of two case studies of social investment which has been implemented in the selected European countries. The first one is the „Big Society Capital” and the second is ASOS Programme. At the end of the paper the author discusses the main critical points which refer to the social investment paradigm and arouse controversy among scholars. 